\title{
高度求心性視野狭窄症例の読書機能評価の検討
}

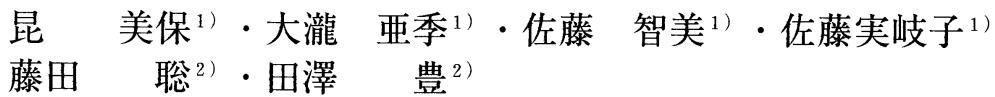

1) 岩手医科大学附属病院 視能訓練室

2) 岩手医科大学 眼科学教室

\section{A study on reading ability of a case with severely concentric visual field contraction}

\author{
Miho Kon ${ }^{1)}$, Aki Ohtaki ${ }^{1)}$, Tomomi Satoh ${ }^{1)}$, Mikiko Satoh ${ }^{11}$ \\ Satoshi Fujita ${ }^{2)}$, Yutaka Tazawa ${ }^{2)}$ \\ 1) Division of Orthoptics, Iwate Medical University Hospital \\ ${ }^{2)}$ Department of Ophthalmology, Iwate Medical University School of Medicine
}

要 約

ロービジョン者へ適切な読書用の視覚補助具を選定する場合、対象物を大きく拡大しすぎると読 書能率が下がることがあり得るので、症例の視力および視野に応じて最も判読しやすい文字サイズ を計測する必要がある。今回、高度な求心性視野狭窄と低視力の女児に対して読書チャート MNREAD-Jによって読書能力を評価し、また所持している拡大鏡の倍率（16 D）が適切か否かを 検討した。

症例は、10年前に摘出手術を施行された頭蓋咽頭腫に伴う両眼視神経萎縮の13歳の女児である。 右眼視力は0.1（n. c.）左眼はnull、視野は約 1.5 度の求心性狭窄であった。視距離 $30 \mathrm{~cm}$ での臨界文字 サイズは $0.6 \log \mathrm{MAR} 、 15 \mathrm{~cm}$ では $0.7 \log \mathrm{MAR} ゙$ あった。 $30 \mathrm{~cm}$ と $15 \mathrm{~cm}$ での最大読書速度は、それぞ れ100.2文字/分と213.2文字/分であった。15cmでの読書速度は、30 $\mathrm{cm}$ の時よりも速かった。この違い は、日常生活の中でスキャニングやトレーシングの能力を自然に体得したことによると推察された。 16Dの拡大鏡の倍率は、通常用いるには強すぎるが、辞書やふりがななどの小さな文字を読み取る には必要であると判断された。

別冊請求先（ $=020-8505 ）$ 盛岡市内丸19番1号

岩手医科大学附属病院視能訓練室 昆美保

Tel. 019-651-5111 Fax. 019-653-2864

Key words : reading ability measurement, concentric visual field contraction, MNREAD-J, low vision 読書能力評価、求心性視野狭窄、MNREAD-J、ロービジョン 


\begin{abstract}
When selecting suitable reading aids for patients with low vision, the most legible character size, which depends on their visual acuity and/or visual field, should be determined, because over magnifying of objects may reduce the reading ability. We evaluated the reading ability by an MNREAD-J reading chart on a girl with severe concentric visual field contraction and with low visual acuity. From the results of the evaluation, we examined whether magnification power ( 16 dioptor ) of her personal magnifying hand glass was adequate.

The case is a 13-year-old girl with bilateral optic nerve atrophy due to craniopharyngioma operated ten years ago. Her visual acuity of the right eye was 0.1 ( n. c.) and the left eye null, and the visual field was concentrically contracted to about 1.5 degree.

Her critical print size for reading was $0.6 \log$ MAR at $30 \mathrm{~cm}$ distance and $0.7 \log$ MAR at $15 \mathrm{~cm}$. The maximum reading speed at 30 and $15 \mathrm{~cm}$ distance were 100.2 and 213.2 characters per minute, respectively. The reading speed at $15 \mathrm{~cm}$ distance was faster than that at $30 \mathrm{~cm}$. This difference may be resulted from spontaneous acquiring of scanning and tracing ability through her daily life. The magnification power of 16 dioptor of her magnifying hand glass was evaluated as too high for her usual use, but may be needed for reading small characters such as dictionaries and agates.
\end{abstract}

\section{I。緒言}

ロービジョン者に読書用の視覚補助具を選定 する場合、その症例の視力や視野の程度および 読書能力によって判読しやすい文字サイズが決 まる。一般に求心性視野狭窄が5度以下の患者へ は、網膜像の拡大を残存視野の範囲内にするた めの倍率の調整が容易な拡大読書器が有効であ る1)とされている。

ロービジョン者の読書能力を判定する方法の 一つに、読書チャートMNREAD-J ${ }^{2) \sim 4)}$ がある。 この読書評価で得られた臨界文字サイズは、処 方する拡大鏡の倍率を選定する場合や、学童で は学習時に最適な文字サイズについての情報を 学校に提供する際に役立てることができる。こ れまでに、高度な求心性視野狭窄の症例に対す る読書評価を行った報告は、未だみられない。 そこで今回、残存視野が約1.5度の求心性視野狭 窄症例に対してMNREAD-Jによる読書評価を行 い、患者にとっての適切な文字サイズおよび患 者が所持している拡大鏡（16D）の倍率が適正 か否かを検討した。

\section{II. 症 例}

症例：13 歳の女览。

疾患名：両眼視神経萎縮

平成5年10月（3歳 3 か月時）、重積するけいれ ん発作を生じて近くの病院の小児科に入院し、 脳下垂体部の頭蓋咽頭腫と診断された。けいれ んの発症前までの視力は良好であったが、入院 後に「視力がなくなったようだ」との母親の訴 えによって10月27日同院眼科を紹介された。視 力は両眼ともにnullであった。翌28日に専門施 設である脳外科研究センターにおいて頭蓋咽頭 腫の全摘出手術が施行された。その後、右眼視 力は 0.2 の改善を得たが、左眼視力はnullのま まであった。それ以降、同眼科において両眼視 神経萎縮として経過が観察されていたが、視力 に著変はなかった。小学校就学前年の平成8年12 月、同眼科からロービジョンケアを目的に当院 眼科を紹介されて初診した。

当科初診時の遠見視力は右眼0.1 (n.c.) 左眼 null。近見視力は右眼 0.2 (n.c.)。視距離を短く して読み取れる最小可読視標によって計測する

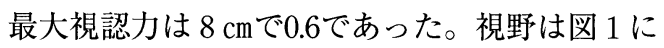
示すように中心に約1.5度を残すのみの高度な求 心性狭窄であった。視力、視野は、ともに当科 の初診時から平成16年 4 月まで不変であった。 平成 9 年 4 月の小学校入学に向けて、同年 1 


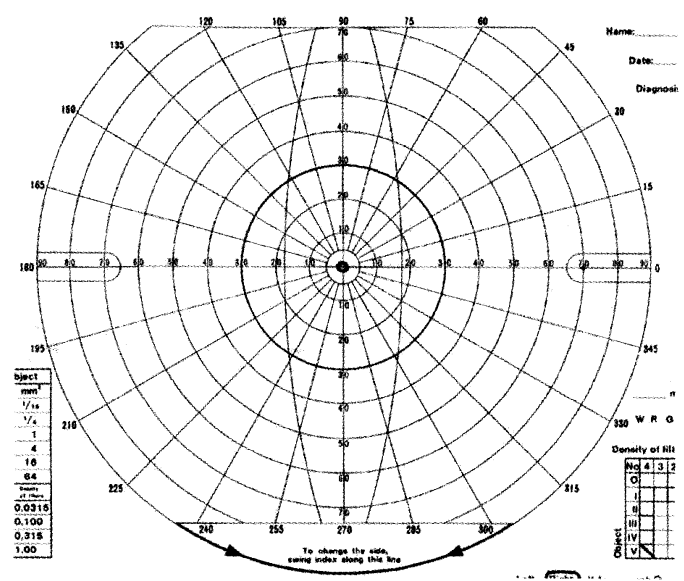

図 1 ゴールドマン視野検査の結果

月からロービジョンケアを開始した。ロービジ ヨンケアの内容と家族および学校の支援の詳細 を表1に示した。小学校の就学にあたっては、 地域の普通小学校が本児童のために弱視学級を 新設することになり、医療側から学校側へ環境 整備のための情報を提供した。家族、学校のい ずれも生活や学習の支援に非常に熱心で、きめ 細かい対応がなされた。小学 1 年時から自宅と 学校に拡大読書器が設置された。小学 3 年時に は、「いわてロービジョン研究会」が視覚障害 者に関わる人々を対象として、以前から開催し ている弱視疑似体験セミナーに本人と両親も参 加した。この経験によって、両親の弱視に対す る理解が一層深まり、白杖の必要性を実感し、 本症例への白杖の導入がスムーズになされる良 い契機となった。一方、 3 年生の後半からは板 書の速度や授業の進行に合わせた追視が遅れる ことに伴う眼精疲労、頭痛、白くぼやけて見え るなどの症状を訴えることがあった。小学 4 年 時から学校側が拡大教科書を採用し、これが使 用された。また、本人の趣味である読書の際の 見えにくさに対してライト付きの拡大鏡（16D） が処方され、これは以後、日常的に使用されて いた。5年生以降になって、眼精疲労、頭痛な どの症状がさらに強くなり、学校では授業を休 んで医務室で過ごす時間が増えてきた。また、 動いているものを眼で捉えることが一層困難に なった。

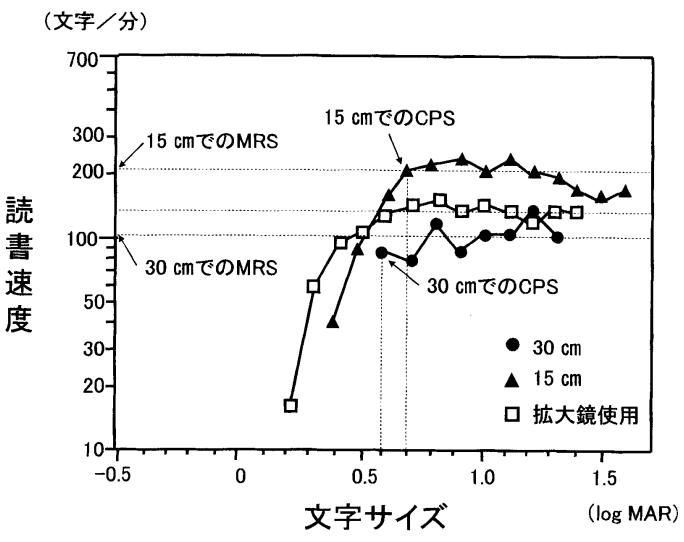

図 2 本症例のMNREAD-J読書チャートによる読書 能力評価

視距離 $30 \mathrm{~cm}$ と $15 \mathrm{~cm}$ のと、および16Dの拡大鏡 を使用したときの結果を示す。

中学校からは盲学校の中等部へ進学した。中 等部2年時にMNREAD-Jを用いて $30 \mathrm{~cm}$ と $15 \mathrm{~cm}$ の 距離（15cmでの視野の大きさは直径約 $4 \mathrm{~mm} ）$ で 読書速度を測定した。また小学校 4 年時に処方さ れ、使用されていた16Dのライト付き拡大鏡の 倍率がこの時期に適正か否かを、各文字サイズ での読書速度を拡大鏡の使用前後で比較するこ とによって判定した。また、目的となる対象物 を見るために必要な倍率は、臨界文字サイズの M sizeの值を対象文字サイズのM sizeの值で割 ることによって算出した。 $30 \mathrm{~cm}$ と $15 \mathrm{~cm}$ の視距離 での検査は、記憶による影響を避けるために 1 か月以上の間隔をあけて行った。

得られた結果を図 2 に示した。視距離 $30 \mathrm{~cm}$ は、臨界文字サイズ (CPS) は0.6 log MAR（Pt sizeは11ポイント) であった。最大読書速度 （MRS）は100.2文字/分であったが、文字サイズ を大きくすると読書速度は変動し、曲線はプラ トーにならなかった（図 2)。各文字サイズで の読書速度を測定する際には、30文字のうち 1 文字でも読めたなら読んでもらうことにしたが、 測定距離が決まっているので近づいてみること ができず、読むことをすぐにあきらめていた。

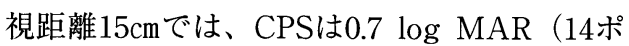
イント）であった。MRSは213.2文字/分で、0.7 $\log$ MAR (14ポイント) から1.2 log MAR (44 ポイント）までの文字の大きさでは、200文字/ 
表 1 本症例に対するロービジョンケアの内容

\begin{tabular}{|c|c|c|c|c|}
\hline 平成 (年) & 学 年 & 医 療 & 家 族 & 学 校 \\
\hline 8 & 就学前 & $\begin{array}{l}\text { 環境整備に関する情報を学校へ提供 } \\
\text { 遠見視に対して } 4 \text { 倍単眼鏡の使用練習 }\end{array}$ & & $\begin{array}{l}\text { 校内の環境整備 } \\
\text { 拡大読書器設置 }\end{array}$ \\
\hline 9 & $\begin{array}{c}\text { 普通小学校 } \\
\text { (搦視学級) } \\
1 \text { 年 }\end{array}$ & $\begin{array}{l}\text { 患児の視機能と同等のシュミレーショ } \\
\text { ンレンズを家族へ貸し出し } \\
\text { 眼鏡処方、黠プレート提供 } \\
6 \text { 倍単眼鏡処方 } \\
\text { 拡大読書器処方 }\end{array}$ & $\begin{array}{l}\text { 周囲からの理解を得るために、 } \\
\text { シュミレーションレンズ購入 } \\
\text { パソコン用文字拡大ソフト購入 } \\
\text { 手作り拡大教科書作成 } \\
6 \text { 倍単眼鏡、拡大読書器購入 }\end{array}$ & $\begin{array}{l}6 \text { 倍単眼鏡購入 } \\
\text { 書見台設置 } \\
\text { 特定教科の個別学習開始 }\end{array}$ \\
\hline 10 & 2 年 & & $\begin{array}{l}\text { 電気スタンド購入 } \\
\text { 点字ものさし購入 } \\
\text { 机の上からの落下防止枠を製作 }\end{array}$ & $\begin{array}{l}\text { 特定教科の個別学習開始 } \\
\text { 黒板の代用としてホワイトボード購入 } \\
\text { 教材を拡大コピーして使用 }\end{array}$ \\
\hline 11 & 3 年 & $\begin{array}{l}\text { 白杖の携帯を勧める } \\
6 \text { 倍単眼鏡を破損したため再処方 }\end{array}$ & $\begin{array}{l}\text { 弱視疑似体験セミナーに参加 } \\
\text { 盲学校見学、歩行訓練 } \\
\text { 白杖、6 倍単眼鏡再購入 }\end{array}$ & $\begin{array}{l}\text { 特定教科の個別学習開始 } \\
\text { 生徒、教員間で弱視疑似体験 }\end{array}$ \\
\hline$\overline{12}$ & 4 年 & ライト付き拡大鏡（16D）処方 & $\begin{array}{l}\text { 盲学校見学、歩行訓練 } \\
\text { ライト付き拡大鏡（16D）購入 }\end{array}$ & $\begin{array}{l}\text { 特定教科の個別学習開始 } \\
\text { 特定教科の拡大教科書使用 }\end{array}$ \\
\hline 13 & 5 年 & $\begin{array}{l}\text { 動いている物を眼で捉える方法を説明 } \\
\text { 視野と距離の関倸を説明 } \\
\text { 逆単眼鏡の説明 }\end{array}$ & 点字の自主学習 & $\begin{array}{l}\text { 特定教科の個別学習開始 } \\
\text { 特定教科の拡大教科書使用 }\end{array}$ \\
\hline 14 & 6 年 & & 点字の自主学習 & $\begin{array}{l}\text { 特定教科の個別学習 } \\
\text { 特定教科の拡大教科書使用 }\end{array}$ \\
\hline 15 & $\begin{array}{c}\text { 盲学校 } \\
\text { 中等部 } 1 \text { 年 }\end{array}$ & & 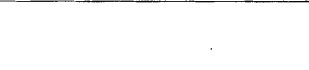 & 特定教科の挔大教科書使用 \\
\hline 16 & 2 年 & MNREAD-J による読書評価 & & 特定教科の拡大教科書使用 \\
\hline
\end{tabular}

分以上の読書速度を保つゆるやかな山型の 1 相 性の曲線を示した（図 2)。

患者が所持していた16Dの拡大鏡を使用する と、MRSは133.2文字/分となり、読書速度は 15 $\mathrm{cm}$ の場合よりも低下したが、拡大鏡を使用しな い時には見えなかった $0.2 \log$ MAR（4.4ポイン

ト）の文字まで読み取ることができた。

中学 2 年生用の普通教科書の本文の文字ポイ ント数（10.5〜13ポイント）に相当するM size は1.6で、拡大教科書のポイント数（19２2ポイ ント）に相当するM sizeは3.2であった。したが って、必要な倍率は $1.25 \sim 0.08$ 倍となり、計算上 は所持していた拡大鏡を使用する必要はないと の結果になった。しかし辞書や漢字のふりがな などのポイント数（ 6 〜 8゚イント）に相当す るM sizeは1.0であり、これを読むためには 2 倍 以上の倍率が必要になると判断された。

\section{III. 考按}

読書チャートMNREAD-Jには、1.3〜 - $0.5 \mathrm{log}$ MARの視力に相当するサイズの文字が表示され ている（図 3 ）。それぞれの大きさの文字をで
きるだけ早く音読してもらい、その読書速度と 誤答数を計測することによって読書の困難度を 評価することが可能である。この読書評価で得 られたパラメーター相互の関係について、正常 者の 1 例を図 4 に示した。この被検者のCPSは、 $0.1 \log$ MAR、MRSは400.5文字/分、読書視力 （RA）は-0.14 log MARである。CPS以上に文 字サイズを大きくしても読書速度は速くならず、 読書速度を表す曲線はプラトーになる。CPS 0.1 log MAR（Pt sizeは3.5ポイント）のM sizeは 0.5であることから、この被検者は新聞の文字を 読む際には、拡大鏡は必要ないと判断できる。

一般に、読書は一度に視野に入る文字数が 5 ～6 文字より少なくなると困難になり ${ }^{5) 、 ま た ~}$ 中心視野が10度以下になった場合には、高いス キャニング能力が必要になる ${ }^{11}$ とされている。 今回の症例のように、視野が約1.5度という高い 損失率の求心性狭窄では、 $15 \mathrm{~cm}$ の距離で視野の 中に14ポイントの文字が1文字入るくらいの大き さになる。しかし、最大視認力は $8 \mathrm{~cm} に$ 近づい

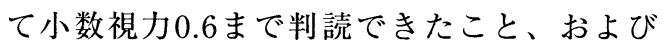
MNREAD-Jを $30 \mathrm{~cm}$ の距離で行った時よりも $15 \mathrm{~cm}$ の距離の方が読書速度は速かったことから、こ 


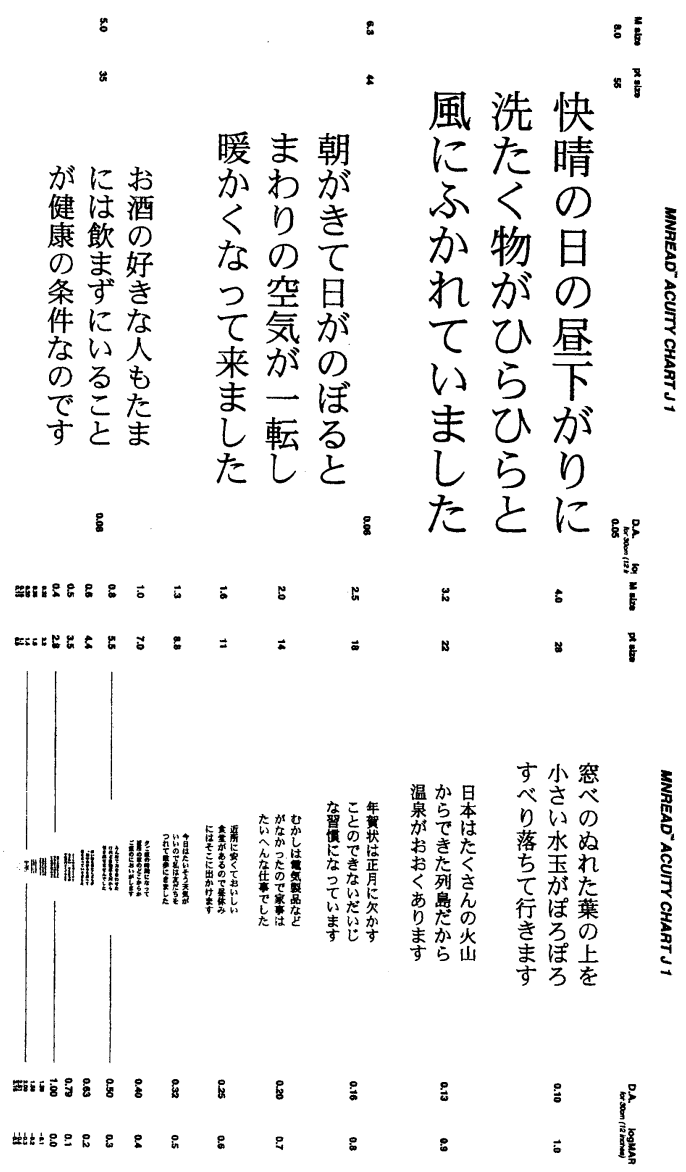

図 3 MNREAD-Jの読書チャート

各文字サイズとも句読点のない 30 文字の文章 から成る。

新聞の文字を読むのに必要な拡大率（M size）、 印刷文字のポイントに換算した值（Pt size）、 小数視力值(D.A.)、視距離 $30 \mathrm{~cm}$ の時の $\log \mathrm{MAR}$ 視力值（log MAR）が示されている。

の症例にとっては網膜に結像する大きさを拡大 すると文字が読みやすくなることが判明した。

視野狭窄があっても、視力が日常生活に不自 由を来たさない程度に良好な場合は、マイナス ルーペや膜プリズムなどの視野拡大補助具が有 効な場合がある。しかし、これらの使用は同時 に視力の低下や複視などが生じるので、本症例 のように視力が良好でない場合には、文字を拡 大するか距離を近づけることによって網膜像を 大きくする方法を選択した方が良いと考えられ る。

MNREAD-Jを用いたこれまでの臨床報告によ

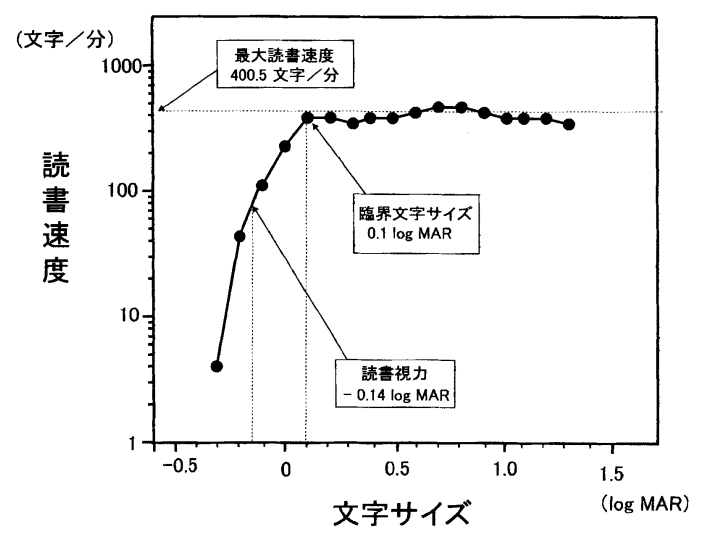

図 4 MNREAD-Jによる正常被検者の読書評価のパ ラメーター

この被検者の臨界文字サイズは、0.1 log MAR (3.5ポイントの文字)、最大読書速度は400.5文 字/分、読書視力は-0.14 log MAR（約 2 ポイ ントの文字）である。臨界文字サイズ以上に 文字サイズを大きくすると、読書速度の曲線 はプラトーになる。この結果から新聞の文字 を読むには拡大鏡は必要ないと判定される。

ると、網膜色素変性による輪状暗点をもつ症例 の読書速度と文字サイズとの関係は、中間の文 字サイズで読書が困難になる 2 相性の曲線にな る ${ }^{6)}$ 。また求心性視野狭窄のあるロービジョン 症例の読書速度は、ある文字サイズで読書速度 が最大に達するが、その文字サイズよりも大き

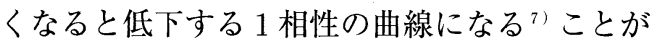
すでに報告されている。今回 $15 \mathrm{~cm}$ の視距離で得 られた 1 相性の読書速度の曲線は、0.7から 1.2 $\log$ MARまでの文字の大きさでは、200文字/分 以上の読書速度を保つ山型の緩やかな曲線であ つた。つまり、視野に 1 文字がぎりぎり入る 14 ポイントから、視野の直径よりも約 4 倍も大きな 44ポイントの文字までを同等の速度で読みとる ことができ、これは驚くべき結果であった。こ のように文字サイズを大きくしても読書速度が 下がらなかった要因として、1）視覚からの情 報の入力に重要な中心視野が残存していたこと、 2）視野狭窄が急激に生じたのではなく、また 長期間変化なく経過し、その間に本児なりの適 応力、すなわちスキャニングあるいはトレーシ ングの能力を体得していたこと、3）趣味が読 
書であることを配慮して、見ることに関するモ チベーションが下がらないように就学前から口 ービジョンケアを開始したこと、4）家族や学 校を中心とした周囲の協力体制が充実していた ことなどが推察される。したがって、本症例へ のロービジョンケアを行う上では、視野の狭窄 度よりも文字の拡大を優先して配慮した方が効 果的であることが示された。

本症例が使用していた拡大鏡の倍率は、中学 2 年生の現在では、拡大教科書はもとより、普 通教科書であっても倍率が強すぎる結果となっ た。しかし、患者はこの拡大鏡を日常的に、特 に 6 〜 8 ポイントの辞書や漢字のふりがななど の小さな文字を読み取るときには使用しており、 状況によってはこの倍率でも適当であると考え られた。視覚補助具の適正な倍率の決定には、 症例が使用する上での目的や方法にきめ細かく 対応した判断が重要である。

\section{IV ．まとめ}

今回の症例を通じて、高度な求心性視野狭窄 の症例に対して視覚補助具を選定する場合、残 存視野を上回る大きさに文字を拡大すると、読 書能率は低下するが文字は見えやすくなること が分かった。また、原疾患の経過期間や残存視 機能の状態、患者の意欲やニーズなどによって も、ロービジョンケアの内容が異なるので、こ れらに十分に配慮する必要があることが再認識 された。MNREAD-Jは、実際の場面に近い状態 で読書能力の評価や視覚補助具の倍率の選定が
可能であり、ロービジョンケアを行う上で有益 であると思われた。

\section{参考文献}

1) 川端秀仁：ロービジョン補助具と視野との関 係. 丸尾敏夫 (編) : 眼科診療プラクティス 61. 40-41, 文光堂, 東京, 2000 .

2 ）小田浩一, Mansfield JS, Legge GE : ロービ ジョンエイドを処方するための新しい読書評 価表 MNREAD - J. 第 7 回視覚障害リハビ リテーション研究発表大会論文集 : 157-160, 1998.

3 ）中村仁美, 小田浩一, 藤田京子, 湯澤美都子 :MNREAD-Jを用いた加齢黄斑変性患者に対 するロービジョンエイドの処方。日視会誌 $28: 253-261,2000$.

4 ）藤田京子：中心視野障害とクオリテイオブラ イフ．－加齢黄斑変性を中心に一。日視会誌 $33: 43-48,2004$.

5 ) 小田浩一：ロービジョンの読書困難を測定し エイドを適切に選択するための読書チャート MNREAD-J (3)。弱視教育39，22-26， 2002.

6 ）中村仁美, 小田浩一, 湯澤美都子：輪状暗点 が拡大した症例における読書能力の変化. 臨 眼55：607-610, 2001 .

7 ) Mansfield JS, Legge GE, and Bane MC : Psychophysics of reading. XV: Font effects in normal and low vision. Invest Ophthalmol Vis Sci 37: 1492-1501, 1996. 